\title{
THE LEXICON OF DAFYDD AP GWILYM's POETRY
}

\author{
DAFYDD JOHNSTON
}

\section{Introduction}

The eclectic breadth of Dafydd ap Gwilym's lexicon has long been recognised as a key feature of his poetry. ${ }^{1}$ The time is now ripe for a detailed study, drawing in particular on two recently completed resources, the historical dictionary of Welsh, Geiriadur Prifysgol Cymru, ${ }^{2}$ and the electronic edition of Dafydd ap Gwilym's poetry, ${ }^{3}$ launched in 2007 , which presents improved texts and interpretations. This paper will offer a preliminary survey and consider some methodological issues encountered in the analysis and classification of the lexicon.

The corpus under consideration consists of the 147 poems accepted as the work of Dafydd ap Gwilym in the new edition. A further twenty poems of uncertain authorship have been excluded from the present study, as, of course, have the four poems by Gruffudd Gryg which form part of the bardic debate with Dafydd. ${ }^{4}$ The total number of lines in this corpus is 7,136 . There might be something to be said for treating the eleven poems in the awdl and englyn metres separately, ${ }^{5}$ since they continued a traditional vocabulary and style, whilst the new cywydd metre, which makes up the remainder of the corpus, was clearly a platform for linguistic change. However, a good deal of that traditional vocabulary was in fact taken over into the cywydd, where it was juxtaposed with new words from the contemporary colloquial language. It is therefore deemed appropriate to analyse the entire corpus as a single unit, whilst bearing in mind that the older metres can skew statistics on matters such as use of archaic vocabulary.

A far greater number of poems have survived by Dafydd ap Gwilym than by any of his bardic contemporaries, and the corpus is sizeable enough to allow for meaningful analysis of the lexicon. However, a similarly eclectic and inventive use of language is apparent in the work of other early practitioners of the cywydd, notably Madog Benfras, Gruffudd Gryg, Llywelyn Goch ap Meurig Hen and Iolo Goch, ${ }^{6}$ and this evidence must be taken into account in

\footnotetext{
${ }^{1}$ For instance Bromwich 1986: xiv-xvi, 8-9, 82-4.

${ }^{2}$ The first edition was completed in 2002 (henceforth 'GPC1'), and work is in progress on a revised edition of letters $A-B$ (henceforth 'GPC2').

${ }^{3} \mathrm{http}: / /$ www.dafyddapgwilym.net (henceforth 'DG.net'); references are by poem and line, which are also applicable to the print edition (Johnston et al 2010).

${ }^{4}$ DG.net poems $23,25,27,29$, and 152-71.

${ }^{5}$ DG.net poems 1, 2, 5-9, 11, 12, 17, 31.

${ }^{6}$ See Lewis 2007, Lewis \& Salisbury 2010, Johnston 1993 and 1998.
} 
drawing any conclusions about the development of the Welsh language in the fourteenth century. This was certainly a period of considerable linguistic change due to socio-political factors in the wake of the Edwardian Conquest, particularly urbanisation, increase in commerce, and the concomitant spread of English, all of which are evident in the work of this generation of poets.

A specifically literary factor which may have led to a broadening of verbal range is the instability of genre in fourteenth-century poetry. Satire (dychan) seems to have had its own distinctive lexical register, first substantially attested in the collection preserved in the Red Book of Hergest ( $c$. 1380-1420); but what is remarkable about many of the early cywyddau is the combination of eulogy and satire, celebration and complaint, both in praise and love poetry, which produced mixed registers and jarring linguistic juxtapositions of old and new, literary and colloquial, native Welsh and English loanwords. The creative potential of this mixing of genres and styles is most evident in the work of Dafydd ap Gwilym, whose language has a particularly strong emotive quality with both positive and negative force.

A term which Dafydd repeatedly associates with the composition or performance of song is berw (literally 'boiling, bubbling'). The suggestion of a spontaneous overflowing of language is reinforced in this passage of selfdescription by the phrase yn llawn iaith and by the association with strong emotion:

Yn lluniwr berw oferwaith,

Yn llawen iawn, yn llawn iaith. ${ }^{7}$

A composer of light-hearted poetry, very joyful, abounding in language. ${ }^{8}$

An extensive 'word-hoard' would of course have been a prerequisite for a professional poet working in any language, and in Welsh lexical resources were stretched to the utmost by the demands of cynghanedd, which is seen to operate as a strict rule-based system for the first time in the work of Dafydd ap Gwilym himself. Vocabulary would no doubt have been deliberately cultivated as an aspect of bardic education, as evidenced by the phrase amlder Cymraeg ('copiousness of Welsh'), which occurs in the triads of the bardic grammars as one of the three things which strengthen a poem (Williams \& Jones 1934: 17).

Dafydd ap Gwilym has a particularly wide range of synonyms for the recurrent thematic elements in his poetry, as anyone who has attempted to translate his work will be well aware. For the primary subject of most of his

\footnotetext{
${ }^{7}$ DG.net 82.9-10; berw is used in the same context at 8.40, 36.35, 36.46, 44.3, 83.48, 91.17 and 129.35. On Dafydd ap Gwilym's use of llawn see Elena Parina's paper in this volume.

${ }^{8}$ All translations are from DG.net.
} 
poetry, a girl, he has the standard merch (conveniently rhyming with serch 'love') and morwyn, three other nouns, bun, dyn (as both masculine and feminine) and rhiain, the simplex adjective gwen and the two compounds meinir and meinwen, as well as several other less common compound formations. To convey the quality of brightness or radiance which was such an essential feature of feminine beauty, Dafydd had at his disposal the following range of adjectives, fifteen in total (as well as various combinations in compound): aur, claer, disglair, eglur, eirian, euraid, fflwch, gloyw, golau, gwyn, hyloyw, llathr, llywy, mygr, pefr. These are often used in clusters, together with metaphorical phrases like lliw ewyn 'colour of foam' to give density to descriptive passages, such as the opening of the address to St Dwynwen and the poem comparing Morfudd to the sun. ${ }^{9}$ It is of course debatable whether all of these are really synonyms in the strict sense of the term, and some certainly have other connotations, such as aur of 'wealth' and gwyn of 'purity' or 'holiness'; but nevertheless all seem to have been more or less interchangeable in the context of what might be called the 'brightness topos'.

It is possible to differentiate between some of the adjectives in this list from a diachronic perspective, since llywy, mygr and pefr were archaic words which hardly survived in the language after the fourteenth century (although the verb pefrio 'to sparkle' is still in use today). Some care needs to be taken in interpreting the data on such words as presented in GPC, because like many other archaisms they were noted in Renaissance dictionaries, such as the Dictionarium Duplex by John Davies of Mallwyd (1632), which were a source for neo-classical writers from the eighteenth century onwards, thus artificially prolonging the lifespan of words which were no longer current in the language. Davies's uncertain treatment of llywy, noting teg, gwyn, disglair on the authority of a word-list by the sixteenth-century poet Wiliam Llŷn, but also proposing a specious connection with llyw 'governor', is a clear indication that the word was no longer current in his time.

A diachronic approach to Dafydd ap Gwilym's lexicon can identify two opposing tendencies, archaism and neologism, which indicate that the language was undergoing a process of transition. On the one hand, there are a number of words attested in earlier literature which are hardly used after Dafydd ap Gwilym. On the other hand, there is a larger group of words which are first attested in his work, many of which are still common in the modern language. A third group of words which occur only in Dafydd's work could represent either tendency, and some of these are surely an indication of his lexical creativity.

\footnotetext{
${ }^{9}$ DG.net 48.1-6, 111.1-26.
} 


\section{Archaic vocabulary}

Although it is not easy to define the archaic element in Dafydd ap Gwilym's lexicon precisely, the typical profile of this group is words which occur in court poetry before 1300 and/or in the early prose, may continue to be used by the later gogynfeirdd, but are either unattested or rare after the fourteenth century other than in dictionaries (where they are often identified as archaic and sometimes misunderstood) and subsequent learned usage as explained above. Crucially, these words were not used in the translations of the Bible and did not become part of the modern literary language. I have identified 83 words of this type, of which 21 are unattested outside dictionaries after the work of Dafydd ap Gwilym himself. Although the absence of examples of these words does not constitute positive evidence that they did not remain in use, nevertheless the substantial number of words in this category is a strong indication that Dafydd was drawing on a literary vocabulary which was already obsolescent in his own time. Indeed, the conservative nature of the bardic tradition meant that words continued to be used in poetry well after they had ceased to be current in other contexts, and at least another thirty words could be added to this group by extending it to include vocabulary used by fifteenth-century poets (in some cases perhaps deriving from Dafydd ap Gwilym's work).

Examples of words occurring for the last time in Dafydd's poetry are gwerling 'lord' (87.12), and mynwyd 'delight' (93.51). A particularly rare word is cynnwgl 'patchwork', otherwise attested only in law texts, which had to be restored from corrupt manuscript readings in one of Dafydd's satires. ${ }^{10}$ The fact that the word had been lost in transmission is an indication that it fell out of currency soon after Dafydd's time.

A case which raises questions about the transmission of archaic vocabulary is rhuddfoawg, used by Dafydd ap Gwilym once only, in a passage contrasting his present poverty with his former wealth (referring to his possession of Morfudd):

Cyweithas, hoywdras, hydrum,

Cyfoethawg, rhuddfoawg fûm.

Genial, of a flourishing line, powerful,

rich, [and] wealthy I was.

The word occurs in the title of a triad, Tri Ruduoa6c Enys Prydein, translated by Bromwich (2006: 39) as 'Three Red Reapers (Despoilers/Ravagers) of the Island of Britain'. There are ten instances of this word in the court poetry of the twelfth and thirteenth centuries in the context of marauding warriors,

\footnotetext{
${ }^{10}$ See note on DG.net 31.29 and references given there.
} 
presumably influenced by the triad. ${ }^{11}$ The first element of this compound adjective is plainly rhudd 'red', suggestive of bloodshed, but the second element, apparently bo-, is obscure. Ifor Williams (1938: 277) compares Irish boingid 'cuts, reaps', whilst GPC compares Irish bágach 'warlike'. In his edition of this Dafydd ap Gwilym poem Ifor Williams (1935: 214) proposed the meaning 'wealthy' (followed in the translation quoted above) as a natural consequence of the acquisition of plunder by ravaging, based on the assumption that rhuddfoawg is here synonymous with the preceding cyfoethawg. However, such an assumption is not supported by the three adjectives in the previous line, which have nothing more in common than their positive force. There is one other instance of the word in fourteenth-century poetry, in an elegy by Iolo Goch datable to 1367, where it describes a warrior's helmet, which is not particularly helpful in establishing any essential meaning. ${ }^{12}$

There are no further attestations of the word until John Davies's dictionary, where it is cited in the spurious form rhuddfáog, rhuddfáawg in an attempt to derive it from a supposed root rhuddfa 'scorched ground', influenced by an explanation in the White Book of Rhydderch triad collection which claims that the ravaging rhuddfoawg left nothing growing in his wake. Subsequent usages in eighteenth-century poetry derive from Davies, as the form in - $f a$ - clearly indicates. Although Dafydd ap Gwilym and Iolo Goch were much closer to the period when rhuddfoawg was common in the literary language, they did not necessarily have any more insight into its meaning than John Davies. It is interesting to note that both poets enjoyed the patronage of Rhydderch ab Ieuan Llwyd, who happens to have been the owner of the two primary manuscript sources for this word, the Hendregadredd Manuscript with its collection of the works of the Poets of the Princes and the White Book of Rhydderch with its triad collection. ${ }^{13}$ It is perfectly possible that both Dafydd and Iolo knew of rhuddfoawg from these manuscripts in the context of heroic feats, and used it with some such general meaning as 'magnificent' or 'mighty' to create an archaic aura in their own poetry.

On the other hand, many of the words last attested in Dafydd's work did undoubtedly derive from a living tradition which must have been strong enough to ensure that they were comprehensible to his original audiences, even if the words in question did die out soon afterwards. A case in point is mei- (<IE *medhio-), which occurs as the first element in compounds with the sense 'middle' or 'half', as in meiau 'middle yoke' in law texts and meiwyr 'cowards' and meigoll 'small loss' in court poetry. Two instances of meigoed

\footnotetext{
${ }^{11}$ Note in particular the reference by Dafydd Benfras to Rhun Rhuddfoawg, Costigan 1995: 523.54.

${ }^{12}$ Johnston 1993: 17.73.

${ }^{13}$ See Huws 2000: 249-52.
} 
'small trees' (52.30 and 57.42) and one of meigoel 'partial trust' (120.13) suggest that it was still productive in Dafydd's time, but there are no subsequent attestations.

\section{Sole attestations}

A total of 71 words are not attested outside Dafydd ap Gwilym's work other than in dictionaries. (This total does not include the ad hoc compounds discussed below.) A few of these words probably belong under archaic vocabulary, but no earlier instances happen to have survived. That is surely true of digust in this couplet:

Hyd y gwŷl golwg digust, Hydr yw, a hyd y clyw clust.

As far as clear eyesight can see,

it is powerful, and as far as ear can hear.

If Ifor Williams (1943: 83) is right in deriving cust from the same root as cuddio 'to hide' and the Latin obscurus, then that word, if not the adjective formed by addition of the negative prefix, must have been part of the language long before Dafydd ap Gwilym. There are also words derived from base forms only attested in early literature, such as amhowys 'restless' (90.20) from powys 'rest' (cf. gorff(o)wys). ${ }^{14}$ On the other hand, there are nine borrowings from English/French which were most likely neologisms and may never have become established in the Welsh language: als (28.60), chwitafad (126.5), griors (63.31), hwl (85.39), hymner (148.58), polart (58.59), sietwn (31.27), trimplai (20.30), ysbenser (90.38). But the vast majority of words in this category are secondary formations from common roots, such as allardd 'ugly' (57.35) from hardd, baches 'darling' (107.32) from bach, bwystus 'beastly' (31.9) from bwyst, and gwythlyd 'fierce' (31.45) from gîyth. It is difficult to know whether such words already existed or whether they were ad hoc coinages by Dafydd ap Gwilym, but the sheer number of sole attestations of this type suggests that Dafydd made highly creative use of the morphological resources of the language. The demands of cynghanedd can be seen to have stimulated that creativity in some cases, as when Dafydd describes Morfudd's marriage as the act of going under another man $i$ 'w gwneuthur ... yn feichiog, fy nyn faches 'to be made pregnant, my dear little girl' (107.31-2), where the sound correspondence between the bitter feichiog and the tender faches encapsulates the emotional complexity of the passage.

${ }^{14}$ See GPC1 2867, Williams 1975: 84. 


\section{First attestations}

The most striking aspect of Dafydd ap Gwilym's lexicon is the group of some three hundred words which are attested for the first time in his work. Like the categories already discussed, this one can also be broken down into smaller groups characterised by different historical trajectories. Those which have Celtic or other Indo-European cognates must have existed in the language long before their first recorded usage. On the basis of etymologies given in GPC there are eighteen such words: broch (68.44) callestr (71.26) cychwior (11.34), cyngerth (11.27, 44.53), cyngwystl (130.35), dormach (142.23), ermyg (98.20), ffrom (53.45), hegl (62.20), min (31 instances), mynawyd (127.33), nidro (56.44), nych (8 instances), pidyn (102.19), rhwd (31.84), sil (54.40), tagell (85.36), telm (56.64). In the case of three of these, ermyg, min and nych, earlier attestations of secondary formations (ermygaf, daufiniog, nychdod) are also logical proof of the prior existence of the base form, and the same can be said for ellyll (6 instances), which is attested slightly earlier in the compound ellyllgerdd, and sothach (87.19) in the verb sothachu.

The two largest groups within this category of first attestations, as in the category of sole attestations, are secondary formations and loanwords, predominantly from English but also from French and Irish. ${ }^{15}$ But whereas in the case of sole attestations there is no evidence that the words ever gained any currency in the language, many of the words in this category are well attested after Dafydd ap Gwilym's time. Borrowings such as gwn (85.31), lwc (90.6) and trwsio (72.45), and secondary formations such difyr 'amusing' (133.25) and gweinidogaeth 'ministry' (7.11) are still common in the spoken language today.

In contrast to the group of words known to derive from Celtic or IndoEuropean roots, there is another group amongst these first attestations whose derivation is obscure: cecru $(31.37,63.27)$, ciprys (45.25), cleddiwig (54.30), chwai (31.44, 46, 38.11), geri (128.36), hurthgen (63.35), llorp (63.28), mwygl (28.58), mystrych (62.14), rhull (6.105, 149.6), rhydain (76.21), seldrem (109.60), silltaer (135.1), soeg (31.55, 73.55), sorod (75.13), sothach (87.19), swrn (31.85, 124.9), trwstan (44.60), truth (148.30), tudfach (63.28), tytmwy/tydmwy $(56.65,130.18)$, ymefin (47.14), ymellin (88.28), ysglem (54.60), ysgrowling (54.62), ysgwd (5 instances). A significant number of these have survived in the modern language and belong to a colloquial register with mainly pejorative force: cecru 'squabble', hurthgen 'blockhead', llorp 'shank', soeg 'dregs', sorod 'trash', sothach 'rubbish', swrn 'a lot', trwstan 'clumsy', ysgwd 'a thrust'. This would suggest that Dafydd was drawing on the contemporary spoken language for words which had not previously been used in literature. He did so for the purpose of invective, and it is significant

\footnotetext{
${ }^{15}$ GPC suggests that celg (135.54) and crapach (1.74) are loanwords from Irish.
} 
that several of these words occur in the body of satirical poetry in the Red Book of Hergest. Some of those instances are more or less contemporary with Dafydd ap Gwilym, and the important point is not which poet was the first to use the word, but rather that a generation of poets was widening the language of poetry to include colloquial vocabulary. ${ }^{16}$

Such words tend to occur in clusters, reinforcing the impression that a distinctive register is being used, as in this line describing the speech of one of the Englishmen in Trafferth mewn Tafarn, which contains three first attestations:

\section{Syganai'r delff soeg enau}

The churlish slobber-chops hissed.

The verb syganu contains the rare negative prefix sy- found in syfudr 'dirty, vile' (also first attested by Dafydd; 61.33). There are three other instances in Dafydd's work with reference to hostile speech acts by the magpie, the jealous husband (also described as delff; 55.35), and one of the girls in Llanbadarn church, ${ }^{17}$ and the translation 'hissed' seeks to convey that pejorative quality which is not apparent in the rather neutral meanings such as 'say' and 'whisper' offered in GPC. The precise meaning is difficult to ascertain since the word does not seem to have survived beyond the early modern period.

Another word denoting speech, which is first attested in Dafydd's work, but with a very different subsequent history, is siarad. The precise derivation is uncertain, but GPC tentatively compares Occitan charrado. Both Dafydd's instances refer to the noise made by birds $(37.17,68.37)$, in one case specifically geese, and that usage is attested by William Salesbury in the sixteenth century. But by the late fifteenth century it is used of human speech (a semantic shift paralleled by the English chatter, also originally used of birds), ${ }^{18}$ perhaps initially with negative connotations, ${ }^{19}$ which soon disappeared as siarad became the standard Welsh word for 'talk, speak'. There is other evidence of Dafydd's sensitivity to semantic change, and it is therefore probably no accident that this word is first attested in his work when on the brink of a major shift in usage.

\footnotetext{
${ }^{16}$ Llywelyn Ddu ab y Pastard (another poet from Ceredigion) has ellyll and llorp (Parry Owen \& Evans 1996: 180, lines 110 and 104).

${ }^{17}$ DG.net 36.33, 55.41, 137.25; cf. also Madog Benfras's usage with reference to the speech of a Dominican friar (Lewis 2007: 28, line 11).

${ }^{18}$ The semantic shift from 'clamour, shout' (about a noise produced by a group (either of people or birds)) to dicere is also attested in the history of Russian several times, an important example being govorit (Zaliznjak \& Yanin 2009: 10). I am grateful to Elena Parina for this information.

${ }^{19}$ Note the adjective siaradus 'chattering, garrulous', used by Guto'r Glyn in a derogatory description of himself as an old man (http://www.gutorglyn.net, 117.5).
} 


\section{Semantic change}

One of the clearest examples of Dafydd's awareness of semantic change is his play on the dual meanings of rheg in Merched Llanbadarn. Referring to the curse on him uttered by one of the girls, wtied $i$ ddiawl 'to the devil with him', Dafydd comments:

\section{Talmithr ym rheg y loywferch, Tâl bychan am syfrdan serch.}

I was stunned by the bright girl's curse, meagre payment for stupified love.

This is the first attestation of rheg in the sense of 'curse', which soon superseded the older 'gift' (a sense taken over by the derivative anrheg) ${ }^{20}$ But that older sense is acknowledged here in the second line, as if the curse was the girl's gift in payment for his devotion. For the wordplay to work both meanings must still have been current, or, in other words, the semantic shift was not yet completed.

Rheg is one of a group of words which are attested earlier, but used by Dafydd ap Gwilym in a new sense, and which can therefore be regarded as first attestations of that particular sense. Several of these words are of thematic significance in his poetry. Firstly, there are two terms relating to the practice of poetry itself. In his defence of love poetry against the criticism of the Grey Friar Dafydd uses cyfanheddu and its abstract derivative cyfanheddrwydd (148.66 and 76), originally 'to inhabit', in the developed sense of 'to entertain, make merry' with reference to his own work. This new sense is also attested in the Red Book of Hergest bardic grammar, where kyuanhedu is listed as one of the three attributes of a teuluwr. ${ }^{21}$ For the concept of satire or mockery which is such a prevalent feature of the work of Dafydd and his contemporaries the word testun, originally 'text, subject', was given a specialised literary sense, also evidenced in the verb testunio, which is listed as one of the three branches of teuluwriaeth in the bardic grammars. ${ }^{22}$ Secondly, on the topic of sexual behaviour there are several new usages. Dafydd has the first instances of the ecclesiastical terms efengyl and pacs in the sense of 'kiss' $(65.38,83.25)$, and it is typical of his bold use of neologisms that both refer not to the kiss of peace but to a lovers' kiss. (One might compare his use of gwn as a metaphor for his penis in 85.31.) And for the concept of sexual lust and promiscuity Dafydd uses the adjective anllad and the abstract noun anlladrwydd (31.25,

\footnotetext{
${ }^{20} \mathrm{GPC} 1$ compares the semantic development of the Latin cognate *prex.

${ }^{21}$ Williams \& Jones 1934: 17. In the corresponding passage in the Llanstephan 3 grammar digrifwch is used instead (ibid., 37).

${ }^{22}$ DG.net 106.30 and 39; Lewis 2007: 45, line 48; Williams \& Jones 1934: 6, 25 and 46.
} 
141.1, 85.37). The only instance of the word earlier than Dafydd is from twelfth-century court poetry, where it is used in a heroic context in the positive sense of 'ardent, passionate', ${ }^{23}$ but later usage is uniformly negative, 'wanton, lustful'. One of the two instances in Dafydd's work is in a satire and is clearly negative (31.25); but the other, in this opening line of a poem about a girl who swore an oath that she had had no sexual relations with the poet, is more ambiguous:

\section{Y ferch anllad a'm gwadawdd}

The passionate [or 'wanton'] girl contradicted me

Since this short poem hinges on the question of whether the girl's oath was true or false, the potential ambiguity of anllad is crucial. If the word could still be understood in a positive sense then the girl's oath might be true, but the weight of evidence from the fourteenth century suggests that it would have been understood in the negative sense and the girl's oath would therefore most likely be false, as the poet claims.

Semantic ambiguity deriving from the coexistence of positive and negative meanings of a single word is a feature of Dafydd's poetry which I have discussed elsewhere, focusing in particular on the dual meanings of moral terms such as balch 'splendid/proud' and segur 'idle/secure' and the instability of social terms such as gwreang (Johnston 2008).

\section{Oaths and exclamations}

It is quite appropriate that the earliest instance of rheg in the sense of 'curse' should be by Dafydd ap Gwilym, since his poems abound in oaths and exclamations from the spoken language. Most common of all are religious oaths introduced by myn (33 examples in total), such as myn fy nghred, myn y grog, myn Duw, myn Mair and other names of saints. These often involve contractions typical of emphatic speech, such as dioer $(<D u w$ a wyr $)$ and rho $D u w(<r h o(f) a D u w)$, used to striking effect in the opening line of his address to his penis: Rho Duw gal (85.1).

Exclamations convey a variety of emotion, from the grieving complaint of gwae fi/ni $(34.1,148.1)$, ochan $(92.1)$ and oio $(102.1,124.6)$, through the contempt of $w b$ (59.30), to the triumph of aha (109.40) and the ecstasy/anguish of wi (34.18 and four other instances). Dafydd has several formulae for the formal cursing which is a feature of his complaint poems: amorth Mair (74.52), $i$ ddiawl (69.18, 92.32, 110.36, 137.34), oerfel i (59.43, $62.39,77.45,136.25)$, and pla ar $(137.2,144.52)$.

${ }^{23}$ Jones 1991: 5.48. 
The curse which concludes the complaint about the month of November appears to be an ad hoc formulation:

\section{Dêl iddo, rhyw addo rhwydd, \\ Deuddrwg am ei wladeiddrwydd.}

May he suffer (easy sort of threat)

two misfortunes for his discourtesy.

\section{Abstract formations}

The combination of curse and abstract concept in that last line is characteristic of the lexical range of Dafydd ap Gwilym's poetry. In contrast to the prominence of low-register colloquialisms there is a significant element of learned vocabulary, particularly in the form of abstract nouns. This was by no means a new feature of the language, and Dafydd was able to draw on wellestablished traditions of religious, historical and legal writing in Middle Welsh, much of it associated with Latin texts, for words such as dwyfoliaeth 'divinity' (131.17), tywysogaeth 'principality' (111.22), and gofaniaeth 'smithcraft' (123.3), whilst abstract nouns such as gwrogaeth 'homage' (7.36), tiriogaeth 'territory' $(6.5,7.24)$, and rhwymedigaeth 'alliance' (7.47) also occur in prose tales and court poetry. In Dafydd ap Gwilym's own time the tradition of conceptualisation continued strongly in the bardic grammars, which abound in abstract formations such as disymlrwydd 'dignity'. ${ }^{24}$ And Dafydd himself seems to have coined a number of new abstract nouns, such as gwladeiddrwydd, of which he has two instances (21.50 quoted above and 33.44), based on the adjective gwladaidd 'rustic, discourteous' (20.45, 22.6, $57.53,105.2,108.4)$, and dyledogaeth 'lordship' (90.34), based on dyledog 'nobleman' (cf. tywysogaeth < tywysog). The morphology of abstract formations was particularly flexible, with a number of alternative suffixes which gave scope for creative variation to meet the demands of rhyme and cynghanedd. For instance, to express the important concept of inconstancy from the adjective anwadal Dafydd uses two formations attested in earlier prose texts, anwadalwch (147.12) and anwadalrhwydd (120.38), and also anwadalder (97.22), of which he has the only instance outside dictionaries.

The laws of Hywel Dda were an important source of vocabulary which would have been both archaic and contemporary, since some sections of the laws were still in use in the fourteenth century and the texts had considerable cultural value for Welsh noblemen such as Dafydd's patron Rhydderch ab Ieuan Llwyd. Dafydd uses about thirty legal terms, some of them quite rare, such as dygngoll 'irreparable loss' and cyswynfab 'son disowned by his father'. Most of these are easily identifiable precisely because they have not

\footnotetext{
${ }^{24}$ DG.net 12.29; Williams \& Jones 1934: 56.
} 
survived into the modern language, but diddim in this passage complaining about the moonlight is one which might not be recognised as a legal term:

\section{Nid eiddio serchog diddim \\ Nos yn rhydd na dydd na dim.}

An empty-handed lover does not freely own

either night or day or anything else.

In the modern language diddim (or di-ddim) is commonly used in the sense of 'worthless', but in the law texts it was used to denote a person with no possessions, and here it describes a lover who is not in possession of his beloved. This instance, the earliest in a non-legal context, may represent a step in the semantic development of the word towards its more general modern usage, as seen in another instance by Dafydd with reference to a false oath, $l l w$ diddim. $^{25}$

\section{Compound words}

Compound words increased Dafydd ap Gwilym's lexicon considerably, both as a resource already existing in the language and more especially as a means of creating new ad hoc formations which could be tailored to suit metrical requirements. Compounds are generally regarded as a traditional device which was part of an elevated bardic style. This view is easily justified, given that compounds were a prominent feature of the court poetry of the previous two centuries and of the conservative awdlau of the fourteenth century, and that they are much less common in fifteenth-century poetry.

They might therefore be seen as having similar status to the traditional vocabulary which imparts an archaic ceremonial quality to some of Dafydd's poetry. However, it would be misleading to generalize in this way about his use of compounds. Several studies have shown that compound formations have been an essential feature of the language throughout its history and that certain types of compounds are still current in the modern spoken language. ${ }^{26}$ It is reasonable to assume, therefore, that in creating new compound words

\footnotetext{
${ }^{25}$ DG.net 141.15 (the poem discussed above in relation to anllad). The instance in 108.11, cariad diddim, is probably also in the legal sense, although it is cited under the later sense in GPC1 968.

${ }^{26}$ Morris-Jones 1931: 24-35 is still a useful introduction, and Watkins 1961: 114-31 gives a realistic assessment of the use of compounds in the spoken language, but the most thorough treatment of compounds in modern Welsh is Thomas 1996: 615-33. On mutations in compounds see Morgan 1952: 19-54, 96-100. Zimmer 2000 analyses a large corpus of material from all periods and all genres according to the categories of classical Sanskrit grammar. Loose adjectival compounds, such as araith Ofydd 'possessing the eloquence of Ovid', are surveyed by Jacobs 1996.
} 
Dafydd was drawing on patterns well-established in the contemporary language.

All possible patterns of compound formation occur in Dafydd ap Gwilym's poetry, as follows:

1) noun + noun $=$ noun: draenllwyn 'thorn bush' (36.34)

2) noun + noun = adjective: $e$ dn bysgodfwyd lit. 'fish-food bird', i.e. 'fisheating' (45.6)

3) adjective + adjective $=$ adjective: tewlwyd 'thick and grey' (57.25)

4) noun + adjective $=$ adjective: $d y n$ danheddwyn 'girl with white teeth' (70.19)

5) adjective + noun $=$ noun: gwanfardd 'weak poet' (93.11)

6) adjective + noun $=$ adjective: bardd arallwlad 'poet from another land' (59.19)

7) noun + verbal stem = adjective: f'aur anrhydeddgael 'my darling who receives honour' $(89.31)$

8) verbal stem + noun = noun: planbren 'planting-stick, dibble' (85.42)

9) verbal stem + noun = adjective: paun haeddfawl 'praiseworthy peacock' (123.22)

The most common types of compound in Dafydd's poetry are 1, 3, 4 and 5, and these are also the most common in the modern language, for instance bwystfil 'wild beast' (1), hirfaith 'prolonged' (3), troednoeth 'barefoot' (4) and llwydrew 'frost' (5). Type 4 has been particularly productive with a part of the body as a first element describing a person, often with pejorative effect, such as boldyn 'tight-bellied' and penboeth 'hot-headed'. This type is used by Dafydd as a means of personification with a strongly colloquial flavour, as when he describes a ruined house as tinrhwth 'gaping-arsed' (151.1; a word also used in satires of the same period) and a magpie as trwynllem 'sharpnosed' (36.34).

The most remarkable run of compounds occurs in the opening paragraph of Serch fel Ysgyfarnog, where fifteen are used to describe the hare (75.1-22). In view of superstitions which are known to have existed about the naming of the hare, it is significant that the standard word for the creature, ysgyfarnog (used by Dafydd as the very first word of another poem about a hare; 76.1), does not occur at all in this poem. The first of the fifteen compounds, glastorch (75.3; literally 'pale-ringed one'?), is attested elsewhere as a name for a hare, and the whole run can be seen as a series of circumlocutions avoiding a taboo. Compounds were also a means of expressing hybridity, seen here in gwrwraig (75.9; literally 'man-woman', another sole attestation outside dictionaries) referring to the supposed androgynous nature of the hare.

The description of the hare is a striking example of the clustering of compounds which is a stylistic feature of a number of Dafydd's poems. A single seven-syllable line can consist of three compounds, and the juxtaposition 
of different types produces a virtuoso effect, as seen in the first line of this couplet in contrast to the simplicity of expression in the second line:

Gwanfardd addfwyndwf gwinfaeth

Oeddwn gynt iddi yn gaeth.

A weak, wine-bred poet of shapely body

Was I once in captivity to her.

On the other hand, a single compound can be used with impressive effect, as in this arresting opening line, where the compound reproduces the unusual sequence of consonants in the personal name:

\section{Dyddgu ddiwaradwyddgamp}

(87.1; cf. anrhydeddgael 89.31)

Dyddgu of faultless accomplishments

It is clear that Dafydd made very strategic use of compound words, encompassing literary modes from praise to satire and a range of registers from elevated to colloquial. Although compounds can be studied as a discrete linguistic feature, they fulfilled a variety of stylistic functions and can be seen to reflect the heterogeneity of his lexicon as a whole.

\section{Conclusion}

Much detailed work remains to be done on various aspects of Dafydd ap Gwilym's lexicon, such as the breakdown of neologisms into semantic categories, patterns of word formation, and comparisons with other fourteenthcentury poetry and prose texts. This preliminary survey has mainly taken a diachronic approach, focusing on old and new vocabulary as evidence of linguistic change. But the greater part of Dafydd's lexicon - perhaps as much as $70 \%$ - consists of the core vocabulary of the language in all periods, and there is scope for semantic analysis of the use of common words, as seen in Elena Parina's contribution to this volume, and for studies of lexical fields such as sensory perception and cognitive experience. Nevertheless, it is hoped that enough has been said to demonstrate the richness of Dafydd ap Gwilym's lexicon and its potential as a case-study for the history of the Welsh language.

University of Wales Centre for Advanced Welsh and Celtic Studies, Aberystwyth 


\section{Abbreviations}

DG.net http://www.dafyddapgwilym.net.

GPC1 Thomas, R. J. et al., eds., 1950-2002, Geiriadur Prifysgol Cymru, Cardiff.

GPC2 Bevan, G. A., Donovan, P. J., eds., 2003-, Geiriadur Prifysgol Cymru, Cardiff ( $2^{\text {nd }}$ ed. $)$.

\section{References}

Bromwich, R., 1986, Aspects of the Poetry of Dafydd ap Gwilym, Cardiff.

Bromwich, R., ed., 2006, Trioedd Ynys Prydein [The Triads of the Island of Britain], Cardiff ( $3^{\text {rd }}$ ed.).

Costigan, N. G. et al., eds., 1995, Gwaith Dafydd Benfras ac Eraill o Feirdd Hanner Cyntaf y Drydedd Ganrif ar Ddeg [The Work of Dafydd Benfras and Other Poets of the First Half of the Thirteenth Century], Caerdydd.

Huws, D., 2000, Medieval Welsh Manuscripts, Cardiff.

Jacobs, N., 'Adjectival Collocations in the Early Cywyddwyr', Cambrian Medieval Celtic Studies 31 (Summer 1996), 55-70.

Johnston, D., ed., 1993, Iolo Goch: Poems, Llandysul.

Johnston, D., ed., 1998, Gwaith Llywelyn Goch ap Meurig Hen [The Work of Llywelyn Goch ap Meurig Hen], Aberystwyth.

Johnston, D., 'Semantic Ambiguity in Dafydd ap Gwilym's “Trafferth mewn Tafarn", Cambrian Medieval Celtic Studies 56 (Winter 2008), 59-74.

Johnston, D. et al., eds., 2010, Cerddi Dafydd ap Gwilym [The Poems of Dafydd ap Gwilym], Caerdydd.

Jones, E. M., ed., 1991, Gwaith Llywarch ap Llywelyn 'Prydydd y Moch' [The Work of Llywarch ap Llywelyn 'Prydydd y Moch'], Caerdydd.

Lewis, B. J., ed., 2007, Gwaith Madog Benfras ac Eraill o Feirdd y Bedwaredd Ganrif ar Ddeg [The Work of Madog Benfras and Other Poets of the Fourteenth Century], Aberystwyth.

Lewis, B. J., Salisbury, E., eds., 2010, Gwaith Gruffudd Gryg [The Work of Gruffudd Gryg], Aberystwyth.

Morgan, T. J., 1952, Y Treigladau a'u Cystrawen [The Mutations and their Syntax], Caerdydd.

Morris-Jones, J., 1931, Welsh Syntax, Cardiff.

Parry Owen, A., Evans, D. F., eds., 1996, Gwaith Llywelyn Brydydd Hoddnant, Dafydd ap Gwilym, Hillyn ac Eraill [The Work of Llywelyn Brydydd Hoddnant, Dafydd ap Gwilym, Hillyn and Others], Aberystwyth.

Thomas, P. W., 1996, Gramadeg y Gymraeg [Welsh Grammar], Caerdydd.

Watkins, T. A., 1961, Ieithyddiaeth [Linguistics], Caerdydd. 
Williams, G. J., Jones, E. J., eds., 1934, Gramadegau'r Penceirddiaid [The Bardic Grammars], Caerdydd.

Williams, I., ed., 1938, Canu Aneirin [The Poetry of Aneirin], Caerdydd.

Williams, I., Roberts, T., eds., 1935, Cywyddau Dafydd ap Gwilym a'i Gyfoeswyr [Cywyddau of Dafydd ap Gwilym and his Contemporaries ], Caerdydd ( $2^{\text {nd }}$ ed.).

Williams, I., 1943, 'Nodiadau Cymysg' [Miscellaneous Notes], Bulletin of the Board of Celtic Studies 11, 77-83.

Williams, I., ed., 1975, The Poems of Taliesin, Dublin.

Zaliznjak, A.A., Yanin, V.L., 2009, 'Берестяные грамоты из новгородских раскопок 2008 года' [Birchbark letters from the 2008 excavations], Voprosy yazykoznaniya (4), 3-12.

Zimmer, S., 2000, Studies in Welsh Word-formation, Dublin. 